\title{
Critical Discourse Analysis of Martin Luther King's Speech in Socio-Political Perspective
}

\author{
Muhammad Aslam Sipra \\ Assistant Professor, Department of GRC (English), JCC, King Abdulaziz University, PO Box 80283, Jeddah 21589 Kingdom of Saudi Arabia \\ E-mail: aslamsipra@yahoo.com \\ Athar Rashid \\ Assistant Professor, Faculty of English Language, Literature \& Applied Linguistics, National University of Modern Languages, Islamabad, Pakistan \\ E-mail: athar.gs@gmail.com
}

Doi:10.7575/aiac.alls.v.4n.1p.27

Received: 01/12/2012

URL: http://dx.doi.org/10.7575/aiac.alls.v.4n.1p.27

Accepted: 04/01/2013

\begin{abstract}
The article presents the Critical Discourse Analysis (CDA) of the first part of King Martin Luther's speech "When I Have a Dream" in socio-political context. The study investigates how it lies on the basis of application of Fairclough version of $\mathrm{CDA}$ in the first part of the text. Moreover, it explicates the terms like social, cultural and political inequalities in the light of text and framework.
\end{abstract}

Keywords: CDA, Socio-political Perspective, 3D Model, Racial Discrimination, Hegemony, Dominance, Social inequalities

\section{Introduction}

The term discourse has several definitions. In the study of language, discourse often refers to the speech patterns and usage of language, dialects, and acceptable statements, within a community. It is a subject of study of peoples who live in secluded areas and share similar speech conventions. Analysis is a process of evaluating the things by breaking them down into pieces. Discourse Analysis simply refers to the linguistic analysis of connected writing and speech. The major focus in Discourse Analysis is the use of language in social context. This article presents a Critical Discourse Analysis of the famous speech by Martin Luther king, Jr. "I Have a Dream" by applying Fairclough 3D Model.

CDA specifically considers how language works within institutional and political discourses as well as specific discourses in order to uncover overt or more often, covert inequalities in social relationships. Language use in speech and writing is seen as a social practice, which 'implies a dialectical relationship between a particular discursive event and the situation(s), institution(s), and social structure(s) which frame it' (Fairclough and Wodak, 1997: 258). Thus, in this two-way relationship, discourse is considered to be socially constitutive as well as socially shaped.

Since discourses are so influential, they can help to produce and reproduce unequal power relations between different ethnicities, social classes, genders, ages, and professional groups. CDA of the selected speech highlights the relationship between language and power. It points out how Martin Luther in front of Washington DC challenges Americans. The persuasive nature of the speech is disclosed through CDA. Martin Luther motivates the audience through language of getting freedom and makes them ready against the racial discrimination

\section{Research Questions:}

1. How does the use of textual/stylistic strategies reflect the view of the Afro-American community in speech?

2. To what extent the ideology of King Martin Luther is reflected through the linguistic choices in the speech?

3. How do the stylistic features represent the broader socio-cultural and political relationship between the white and the black community in America?

These questions are researchable as the focus is on the analysis of the language used in the speech. Researcher analyzed the linguistic choices which are used by the speaker in order to find out the motifs. Language is considered to be the main tool through which one can exert power and show retaliation to the powers exercised in the society by the dominant groups. This project focuses on how speaker tried to raise voice against the hegemonic attitude of white against the black with the help of language and how he tried to promote his ideology and motifs in the mind of the socio-politically oppressed blacks. Researcher analyzes the stylistic devices like metaphors used by the speaker in order to represent the perspective of the black. Power relation between the black and the white are analyzed at wider socioeconomic and political perspective that how white exert power on the black by analyzing the speech through CDA. 


\section{Literature Review}

In this section of the project, researcher has cited 20 references related to the main topic and different variables involved in the research questions. Researcher has tried to knit a strong kind of theoretical basis in this portion to make further grounds clear. Works of different theorists in the broad interdisciplinary field CDA have been elaborated vividly.

Vandijk (1998a) is of the view that CDA is particularly concerned with the analysis of any discourse whether written or spoken from the perspective of discursive practices in a society like hegemony, domination, inequality of basic rights and racial discrimination. Its focus is to examine the exertion of these practices with reference to socio-economic and political perspective.

Fairclough (1993) says that CDA is a kind of analysis of discourse which brings forth odd relationships among different social and ethnic groups. He focuses text and sequential events and then relates them with broader socio-cultural perspective of the discourse of people which reveals uneven and ideology shaped power relations. He explores how power is exercised in a society through hegemonic attitude and ideological text of the elite.

Fairclough (1992) explains three stages for the analysis of a discourse. In first stage CDA analyses the personal experience and knowledge of the speaker by keeping in view his beliefs. Secondly, how social relations affect the discourse and thirdly, speaker realizes about the reality and identity. He is of view that linguistic choices in a discourse like lexical selection and syntactic patterns also reveal the social background and identity of a speaker. He argues that it is the language which shapes discourse and different socio-political views which leads towards the exertion of power relations. Fairclough (1992) is of the view that people belonging to a specific social setup have different relational and expressive norms which is revealed through their speeches. This shows that there is strong tie between the social and linguistic variables. The prime purpose of CDA is to analyze the text in the light of social theory of language functioning of ideological and political processes.

According to Brown and Yule (1985) language is not only used for the description of things rather it is also used for doing things as well. CDA analyses the use of the language in a real context and how language reveals their cultural, social and ethnic backgrounds. They are of the view that choice of lexical and syntactic features of a language represent the broad socio-cultural background of the speakers. Critical discourse analysis focuses on how their language reflects discursive practices in the binary relations.

Halliday's (1978) view regarding this concept is same that language is considered to be a social act because people communicate in a social setup. Language and society are dependent on each other rather directly linked in terms communication. It is the language (text) which shapes and constructs our identities. Same is the case in our context. People who are fluent in English are considered socially and culturally dominant because they speak the language of socially and politically dominant people. In this case, linguistic variable seems to become the identity of that particular class.

According to Fairclough (1995b), linguistic analysis of discourse practice in socio-cultural background is known inter textual analysis. Here the linguistic analysis is the analysis of the text at lexical, syntactic, grammatical and vocabulary level. Cohesion, coherence and organization of the text are also included in this analysis. This analysis focuses on the text by keeping in view all discourse practices.

Fairclough (1992) defines intertextuality as the characteristic of any text in which the text carries the chunks of other texts which become a part of that text. The chunk taken from other text become a complete part of the original one whether it refutes the idea given in the original text or accepts. He divides intertextuality into two types which are 'manifest intertextuality' and 'constitutive intertextuality'. The first type refers to the use of quotations in the texts in order to validate and authenticate the argument. Certain quotes are included in the inverted comas while writing any essay or speech. This type of inclusion of other text is considered as manifest intertextuality. The other is related to discourse structures which lead to novel text production. Fairclough says that this kind of text can be analyzed by doing its linguistic analysis.

Fairclough (1989) described his approach in the perspective of analysis of text as 'critical language study'. His main focus was to unfold the discrimination of social relations and discursive practices which exploits the rights of masses with the help of language used in society. He is the view that language is used as a tool for exercising power and hegemony. Text is the dress of thoughts through which people exert dominance.

Wodak and Fairclough (1995a, 1996) are of the view that language as a practice of creating hegemony, power and dominance is being used in a society. It seems to be a complete reflection of social practices like a mirror. The types of language used among the members of society reveal the social relations like communication of a director of a company with a clerk or peon would clearly draw line and the linguistic choice of director would reveal his/her hegemonic attitude. Historical perspective of discourse plays vital role in getting the meanings of the text. Every text carries certain historical perspectives and contexts which clarify the meanings in that particular context.

Gee (1990) and Sampson (1980) put an argument that CDA systematically interprets discourses with the help of various approaches by keeping in view socio-political and economic contexts. Here, social semiotics plays significant role in the interpretation of discourse because the analysis would be done on the basis of social factors in that specific context.

Fowler (1996) says the perspective of CDA is to produce the knowledge of exploitation and knowing, conscious rising of the people regarding any discourse in socio-cultural context. He is of the view that analyst should focus the 
representation critical orientation instead of criticism of discourses. Critique from CDA perspective would represent the social, economical and political backgrounds of discourses.

Corson (1995) says that critical discourse analysis applies certain techniques like textual and stylistic features to find out the social relations, identities from the linguistic perspective. Discourses whether they reveal the social issues like dominance, hegemony are reflected through text or it is the discourses related to educational systems like schools, official documents are dealt by the analysis of the text.

According to Blommaert(2005) and Jorgensen(2002) critical discourse analysis is considered to be wider and broader which analyses the relation of language within a society and its impact on the discourses. They are of the view that linguistic and social variables in CDA research are closely knitted to each other because whenever we approach any text or discourse, we approach it from linguistic perspective and emphasize how choice of language in a particular discourse pertaining the socio-political context tries to analyze the discursive practices.

Chilton (1996) and Lakoff (1995) argue that metaphors play a significant role in Critical discourse analysis. They are of the view that metaphors in a discourse represent an ideology which leads to reality in that particular context according to an individual's perception. King Martin Luther used some metaphors in his language which reflect his ideology in that socio-political background.

Van Dijk (1991, 1993), media and politics are closely related as media propagates the thought and ideologies of elite. He describes media discourse as an advocate of elite's policy, hegemony and exploitation. It always favours the ideologies of the dominating class and state. Language used by them unfolds the discriminatory attitude of high towards the low.

Ruth Wodak(2001) and Meyer (2001) interpret the term 'Critical' in CDA as the analysis and understanding of the language embedded in social, political and economic perspective. CDA tries to develop connections between the powers exerted through language with a wider socio-political context. The focus seems to be on text primitively because it reflects the ideological and identity basis which are constructed and produced through the social relations. They are of the view that CDA not only traces out the power relations in social practices but it also provides opportunities to challenge and criticize it.

Carroll (2004) is of the view that Critical discourse provides us several dimensions for the analysis of a text or speech as it functions as a theoretical framework (theory) and method (how to use data for the analysis). Critical discourse analysis brings forth both the aspects which sociological and post-modern perspective for the analysis of discourse. Sociological feature is related to functional aspect of language in the constructions and explanation of social relations. It focuses on the use of linguistic features in discourse and how power and hegemony influence the social relations. CDA analyses the abuse of power and hegemonic attitude by focusing through the lens of language. The later analyses the context and dimensions of discourse.

\section{Research Methodology}

Speech of King Martin Luther is analysed by applying Critical Discourse Analysis (CDA). It Analyses whether lexical representation, syntactic organization and coherent speech in a particular socio-cultural context having an ideology influences the cognition of audience. Researcher's contribution is the analysis of the textual/stylistic strategies and interpretation of relational, expressive and representative values in the speech with special focus on wider sociopolitical and economic perspectives.

This research adds to the previous knowledge by focusing and analyzing the speech on the basis of linguistic choices, discursive practices and socio-cultural perspective. It also analyzes as to how certain linguistic structures help the speaker to propagate his/her ideologies effectively and makes others accept heartily.

The data is collected from the historical speech of King Martin Luther delivered on August 28, 1963. The title of this spell bounding speech was 'When I Have Dreams' which reflects the aspirations and demands of all blacks residing in that part of the world. Researcher delimited only first part of the speech which consists of 31 sentences. Fairclough's model has been applied in order to this part of speech. A quarter of million people, gathered in Washington DC from all racial backgrounds to support the American blacks for the equality of rights.

Researcher selected the 3D model and framework proposed by Norman Fairclough(1992). He has introduced three aspects in his model for the critical analysis of any discourse or text. This model consists of text, socio-cultural practices and discursive practices in a society. Text is analyzable as socio-economic and political factors influence the discursive practices in the society. Fairclough (1989) described the objective of this approach as a contribution to the general rising of consciousness of exploitative social relations, through focusing upon language.

Researcher has taken Critical Discourse Analysis (CDA) as theoretical framework of this project. CDA analyses the discourses critically and reveals the social practices like dominance, hegemony, exploitation victimization of the oppressed ones. CDA is an interdisciplinary field which brings social sciences and linguistics at the same platform. Its topics of discussion are linked with ethnicity, hegemonic attitude of high towards low, gender discrimination, dominance, ideology, discursive practices and gender. The parameter of analysis is only language and reveals how discourse manifests discursive practices in a social setup. The topic of this article clearly represents the issues which CDA deals on the primary basis. The topic carries variables like social, cultural, political inequality and ideology which are the core issues discussed by CDA. This theoretical framework provides a complete base and standing for the analysis of above-mentioned variables in the speech of King Martin Luther. 
Ethical considerations are dealt very carefully while conducting this research. As this research is

purely qualitative in its nature, there is no interaction with human subjects. There are no

interviews in this research which could lead towards ethical issues.

Researcher has taken CDA as method for this project. The nature of the research is purely qualitative as the speech is analyzed on the basis of Fairclough's 3D Model. CDA has also been taken as methodology at broader spectrum for the analysis. First part of the speech 'I Have a Dream' has been analyzed on the theoretical base which is CDA. It has been used as tool to investigate the hegemonic attitude and discursive practices of the white against the black.

\section{Discussion and Analysis}

Researcher has collected data from the speech of Martin Luther King 'When I Have Dream'. First 31 lines containing 648 words have been analyzed and interpreted by applying Fairclough's 3D model which talks about expressive, relational and ideational values. It critically analyses the whole text on the basis of three aspects in a broader macro and micro level; which are related to the analysis of linguistic choices (text), discourse practices in the back scene of that particular text and socio- cultural practices keeping in view particularly social, economic and political factors. Researcher has applied CDA as a theoretical framework of this research as it focuses the text which reveals social inequality, racial discrimination or other discursive practices by looking at the text from socio-cultural perspective. It is critical and explanatory in its nature. This approach of Fairclough systematically throws light on all aspects like at first it gives the description of linguistic features used in that particular text. Secondly, it tries to interpret the relation of that particular text with the interaction and thirdly it explains the link of interaction with the broader socio-political variables.

\section{Text Analysis}

Text is one of the main pillars and central to the analysis on Fairclough model. Analysis of text is strongly linked with the analysis of language used by people in real setting. This approach in the beginning was named as 'Critical Language Study' as the special focus was to raise consciousness of socially exploitative relation with special focus on language. Text analysis involves the analysis of lexical choices, cohesion, coherence and different stylistic features which focuses on the particular theme and broader socio-political perspective of the speaker. This leads to the analysis above syntactic level.

This analysis can be divided into two sections. In the first section, there is analysis within the clauses or sentences that highlights the Theme, Rheme, Given and New Information. In the second section, there is analysis of relationship of the sentences or clauses with each other by focusing on the four types of thematic progression. Informative Structure is developed through a series of Theme, Rheme, Given and New Information. This creates an organization in the sentences of the speech. They lend cohesion and coherence to the speech. We make sentences grammatically and thematically correct by following the informative and thematic structure. This cohesion heightens the impact of the message and feelings by the speakers. This gives a power to the speaker to have a deep impact on the audience. It creates a logical sequence within the sentences. The sequence of given and new information also help in making the speech effective. They serve as a bridge between the speakers and the audience. Moreover, Mark and Unmark and Multiple Themes function as a magnet to hold the whole discourse together. In the speech coherence is developed through Given and New information. Audience gets from the speech only one theme through the related sentences that show cohesion and coherence.

Thematic Progression of the speech is developed through Constant Theme Pattern. The selected part of the speech is well knitted, well thought and well organized. It has been created with the help of chain of related ideas and appropriate words focusing on the main idea. This technique keeps the feeling of the audience intact. It encourages to get united and free them from the long slavery. Only Constant Theme Pattern is followed in this speech the rest of the three patterns are not used in the speech. Constant Theme Pattern aims at maintaining the emotional impact on the audience by focusing on the main idea or theme.

Throughout the speech, Dr. King repeats words and sentence. This is a very outstanding feature in this speech called repetition. The term repetition is restricted to mean the case of exact copying of a certain previous unit in a text such as a word, phrase or even a sentence (Leech, 1969). If we study the selected part of the speech more carefully, it is easy for us to find many other examples of repetition used:

.... "One hundred years later, the life of the Negros still sadly crippled by the manacles of segregation and the chains of discrimination". (Luther King, 1963)

..... "One hundred years later, the Negro lives on a lonely island of poverty in the midst of a vast ocean of material prosperity”. (Luther King, 1963)

Here the phrase "one hundred years later" has been repeated four times, clearly indicating that there has been a long time these African-Americans aspiring for the freedom and equal rights without any discrimination based on color and creed.

Parallelism is another syntactic over-regularity. It refers to the exact repetition in equivalent positions but it is different from the common repetition. To put it simply, parallelism means the balancing of sentence elements that are 
grammatically equal. In his speech, Martin Luther King uses parallelism to create a strong rhythm to help the audience line up his ideas. Here are few examples:

...by the manacles of segregation and the chains of discrimination... (Par.2, two parallel noun phrases)

Martin Luther King used the noun freedom 20 times in this speech which reflects that Freedom and inequality are the major themes of the speech keeping in view socio-political background of the speech. Other pronouns like 'We', 'Ours' and 'You' have been used 30,17 and 08 times in speech respectively which indicate the intimacy between the speaker and the audience. Other lexemes like nation, America and justice have also been used several times which indicate that King's speech conveyed the message of justice, equality and unity as one nation.

Metaphor is a stylistic device which is used to associate the abstract ideas with the concrete images. King used metaphorical language in his speech which connects with the concrete images and here in this speech certain contrastive concrete metaphors have been used to enhance the beauty of the speech. For example, to contrast segregation with racial justice, King has contrasted the metaphors of dark and desolate valley (of segregation) and sunlit path (of racial justice). Intertextuality is again one of the important features found in the speech of the king. It refers to the text taken from some other source in order to validate one's perspective. It can be explicit as well as implicit in its nature. The reference given by Martin Luther; "Five score years ago..." [Paragraph 2] refers to Lincoln's famous Gettysburg Address which began "Four score and seven years ago..." This refers to the point that King was speaking in front of the Lincoln Memorial.

\section{Analyzing Context}

This spell bounding speech of Martin Luther King carries a complete contextual background with it. The blacks were deprived of their rights and racial discrimination was at its peak. He fought for the rights of Afro-American people and launched 'Civil Rights Movement' which became the basis of this memorable speech. His struggle for the oppressed blacks turned to be mass movement against the cruel and discriminatory attitude of the Whites. His prime motifs were to get equal rights and to get rid of the discriminatory attitude of Whites towards the Blacks. Negroes were considered socially, economically and politically inferior as compared to the other race living in America. He wanted to have equality for the Negroes on all grounds so that they could work for the progress of nation ultimately. Negroes were considered politically and socially inferior and this speech refers to exploitations of the whites. Luther King tried to make people aware of their rights and that of discriminatory and hegemonic attitude of the whites.

Analysis of Discourse Practices and Socio-Political Aspect of Speech

According to Fairclough (1992) model these two aspects which are discourse practices and socio-political and cultural perspective are of vital importance. Discourse practices refer to execution of social practices through discourse. Discourse is always socially constituted and vice versa. On the other hand socio-cultural and political aspects are also important because they provide a complete overview of the circumstances in which discourses are being constructed. The analysis of discourse practices and socio-political aspects can be divided into three major areas which are Genre, Discoursal analysis and style. Researcher discusses each major area with reference to speech and how they are linked with each other in this particular speech.

Analysis of Genre refers to the analysis of text which relates to the lexical choices used in this speech with broader socio-cultural context. It also refers to the particular identification of patterns in the speech. In the first paragraph flames of withering injustice refers to the harsh and cruel attitude of the white. The words flame means the fire and withering refers to the gloomy and desolate picture of the blacks. Their faces have been withered due to continuous chain of slavery in their neck. The word vast ocean refers to the great economy and wealth of the America. Here, king is of the view that these Negroes are deprived of being an independent individual and they are economically and politically crippled even living in such prosperous and developed state. He used the word nation many a times which indicate that his stance was that the blacks and the whites are one nation without any discrimination.

Style of the speaker carries importance in the critical analysis of any discourse. Expressive and relational values are closely linked with this speech analysis. Expressive value indicates the expression of personal experiences of the speaker. The speaker himself was a Negro and he experienced the same deprivation and indifferent attitude of the white. His involvement and enthusiasm show that his words are expressions of all Negroes. Relational value throws light upon the relation among the speaker and audience. He was evoking audience because he was a part of those who were sufferer and oppressed. He used pronoun 'We' and 'Ours' several times in the speech which ultimately indicate that the speaker considers himself of being a member of that group. Speaker with the help of these lexical choices gets involve in the sentiments of the oppressed ones.

Representational value is of significant importance as it makes the worldview of the audience. It indicates the subject matter of the discussion and particular socio-political background of the speech. Here, the question arises that why is this speech different from others? It differs because of its social and political context as it revolves around one major idea which is social, political and economical inequality in the rights of the blacks. King criticized the American authorities for being not fulfilling the promise which they mentioned in the constitution. Negroes were not given liberty, equal rights and economic equality which were being mentioned in the constitution. 


\section{Conclusion and Recommendation}

The limitations of the study are linked with the data for the analysis on the interpretative paradigms of the research. Only first part of the just one speech is analyzed as it becomes very difficult to handle the whole speech rather all speeches of King Luther. The analysis of the chunk of the speech could not be perfectly analyzed and interpreted.

It can be concluded that in this speech certain textual and stylistic devices have been used very frequently in order to achieve some specific purpose. It carries all those prerequisites which a speech must have to propagate the ideology in a sophisticated manner. It seems to be syntactically well-organized with frequent repetitions emphasizing the main theme which is inequality of socio-cultural rights and racial discrimination on the basis of color and creed. The choice of the lexemes is not well ordered according to situation but also recapitulating background and indicating the relational and expressive values of the speaker. Luther king very impressively and successfully with the help of metaphors and other devices identifies the relationship between the powerful and oppressed. He very persuasively succeeds in achieving the strength and support of the powerless without creating any conflict with the powerful. His speech very peacefully sheds light on the institutionalized social inequalities.

There are certain other factors like social cognition in this speech which can be pointed out in further research. There are other approaches in CDA which can be applied on this speech by keeping in view same patterns. The models proposed by VanDijk and Wodak can also be applied to carry out qualitative nature of research.

\section{References}

Blommaert, J. (2005). Discourse. A critical introduction. Cambridge: Cambridge University Press

Brown, G. and Yule, G. (1985). Discourse Analysis. Cambridge: Cambridge University Press

Carroll, W. (2004). Critical Strategies/or Social Research. Toronto, Ontario: Canadian Scholars' Press Inc.

Chilton, P. (1996). Security metaphors: Cold war discourse from containment to common house. New York: Peter Lang.

Corson, D. (1995). Discourse and Power in Educational Organizations, Creskill: Hampton Press, N.J.

Fairclough, Norman (1989). Language and Power. London: Longman.

Fairclough, N. (1992). Discourse and social change. Cambridge: Polity Press

Fairclough, N. (1992) Discourse and social change. London: Polity Press

Fairclough, Norman (1995a). Critical discourse analysis: The critical study of language. London: Longman.

Fairclough, Norman (1995b). Media Discourse. London: Edward Arnold.

Fowler, R. (1996). 'On Critical Linguistics 1': in Caldas-Coulthard, C. R. and Coulthard, M.

(eds.) Texts and Practices: Readings in Critical Discourse Analysis, London: Routledge.

Gee, J. P. (1990). Social linguistics and literacies: Ideology in discourses. London: The Falmer Press

Halliday, M. A. K. (1978). Language and Social Semiotics. London: Edward Arnold

Jorgensen, Marianne \& Phillips, Louise (2002). Discourse analysis as theory and method. London: Sage Publications

Meyer, M. (2001). Between theory, method, and politics: Positioning of the approaches to CDA. In R. Wodak \& M. Meyer (Ed.), Methods o/Critical Discourse Analysis

Sampson, G. (1980) School of Linguistics: Competition and Evaluation. London: Longman

Van Dijk, T.A. (1991). Racism and the press. London: Routledge

Van Dijk, TA. (1993). Elite discourse and racism. London: Sage Publications. pp.(242-282)

Van Dijk, T.A. (1998a). Critical discourse analysis. Available:

http://www.hum.uva.nl/teun/cda.htm. (1/25/2000)

Wodak, R. (2001). What CDA is about - a summary of its history, important concepts and its developments. In R. Wodak \& M. Meyer (Ed.). Methods of critical discourse analysis. London - Thousand Oaks - New Delhi: Sage Publications. 


\section{Appendix}

\section{Martin Luther King's Speech: 'I Have a Dream' - The Full Text}

By The Rev. MARTIN LUTHER KING Jr.

Aug. 28, 1963

I am happy to join with you today in what will go down in history as the greatest demonstration for freedom in the history of our nation.

Five score years ago, a great American, in whose symbolic shadow we stand signed the Emancipation Proclamation. This momentous decree came as a great beacon light of hope to millions of Negro slaves who had been seared in the flames of withering injustice. It came as a joyous daybreak to end the long night of captivity.

But one hundred years later, we must face the tragic fact that the Negro is still not free. One hundred years later, the life of the Negro is still sadly crippled by the manacles of segregation and the chains of discrimination. One hundred years later, the Negro lives on a lonely island of poverty in the midst of a vast ocean of material prosperity. One hundred years later, the Negro is still languishing in the corners of American society and finds himself an exile in his own land. So we have come here today to dramatize an appalling condition.

In a sense we have come to our nation's capital to cash a check. When the architects of our republic wrote the magnificent words of the Constitution and the Declaration of Independence, they were signing a promissory note to which every American was to fall heir. This note was a promise that all men would be guaranteed the inalienable rights of life, liberty, and the pursuit of happiness.

It is obvious today that America has defaulted on this promissory note insofar as her citizens of color are concerned. Instead of honoring this sacred obligation, America has given the Negro people a bad check which has come back marked "insufficient funds." But we refuse to believe that the bank of justice is bankrupt. We refuse to believe that there are insufficient funds in the great vaults of opportunity of this nation. So we have come to cash this check -- a check that will give us upon demand the riches of freedom and the security of justice. We have also come to this hallowed spot to remind America of the fierce urgency of now. This is no time to engage in the luxury of cooling off or to take the tranquilizing drug of gradualism. Now is the time to rise from the dark and desolate valley of segregation to the sunlit path of racial justice. Now is the time to open the doors of opportunity to all of God's children. Now is the time to lift our nation from the quicksands of racial injustice to the solid rock of brotherhood.

It would be fatal for the nation to overlook the urgency of the moment and to underestimate the determination of the Negro. This sweltering summer of the Negro's legitimate discontent will not pass until there is an invigorating autumn of freedom and equality. Nineteen sixty-three is not an end, but a beginning. Those who hope that the Negro needed to blow off steam and will now be content will have a rude awakening if the nation returns to business as usual. There will be neither rest nor tranquility in America until the Negro is granted his citizenship rights. The whirlwinds of revolt will continue to shake the foundations of our nation until the bright day of justice emerges.

But there is something that I must say to my people who stand on the warm threshold which leads into the palace of justice. In the process of gaining our rightful place we must not be guilty of wrongful deeds. Let us not seek to satisfy our thirst for freedom by drinking from the cup of bitterness and hatred. 